\title{
The unexplored frontier of molecular epidemiology of tuberculosis in patients with rheumatic disease
}

\author{
Mónica Vázquez-Del Mercado ${ }^{1,2,3,8}$, Eduardo A Wilson-Manríquez ${ }^{1}$, Efrain Chavarria-Avila ${ }^{4}$, Esther G Corona-Sanchez ${ }^{1,5}$, Ana L Márquez- \\ Aguirre $^{6}$, Flavio Sandoval-García ${ }^{1,7}$, Beatriz T Martín-Márquez ${ }^{1,2}$, Erika A Martínez-García ${ }^{2,5}$, Rosa E Navarro-Hernández ${ }^{1,8}$, Sergio Duran- \\ Barragan $^{1,2,3,7}$ and Oscar Pizano-Martinez ${ }^{1,7 *}$ \\ ${ }^{1}$ Departamento de Biología Molecular y Genómica, Instituto de Investigación en Reumatología y del Sistema Músculo Esquelético, Centro Universitario de \\ Ciencias, de la Salud, Universidad de Guadalajara, 44340, Guadalajara, México \\ ${ }^{2}$ Cuerpo Académico UDG-CA-703, Inmunología y Reumatología, Instituto de Investigación en Reumatología y del Sistema Músculo Esquelético, Centro, \\ Universitario de Ciencias de la Salud, Universidad de Guadalajara, 44340, Guadalajara, México \\ ${ }^{3}$ Servicio de Reumatología, 004086 PNPC CONACyT, Hospital Civil Dr. Juan I. Menchaca, Guadalajara, Jalisco, México \\ ${ }^{4}$ Departamento de Disciplinas Filosófico Metodológicas e Instrumentales, Instituto de Investigación en Reumatología y del Sistema Músculo Esquelético, \\ Centro Universitario de Ciencias de la Salud, Universidad de Guadalajara, 44340, Guadalajara, México \\ ${ }^{5}$ Departamento de Fisiología, Instituto de Investigación en Reumatología y del Sistema Músculo Esquelético, Centro Universitario de Ciencias de la Salud, \\ Universidad de Guadalajara, 44340, Guadalajara, México \\ ${ }^{6}$ Unidad de Biotecnología Médica y Farmacéutica, Centro de Investigación y Asistencia en Tecnología y Diseño del Estado de Jalisco, 44270, Guadalajara, México \\ ${ }^{7}$ Departamento de Clínicas Médicas, Instituto de Investigación en Reumatología y del Sistema Músculo Esquelético, Centro Universitario de Ciencias de la \\ Salud, Universidad de Guadalajara, 44340, Guadalajara, México \\ ${ }^{8}$ Cuerpo Académico UDG-CA-701, Inmunometabolismo en Enfermedades Emergentes, Instituto de Investigación en Reumatología y del Sistema Músculo \\ Esquelético, Centro Universitario de Ciencias de la Salud, Universidad de Guadalajara, 44340, Guadalajara, México
}

\begin{abstract}
Tuberculosis is a disease that affects a third of the world's population and according to the World Health Organization is considered an important public health issue. Any member of the Mycobacterium Tuberculosis Complex can cause active disease because of $99.95 \%$ genetic homology between these strains; however, this small difference confers specific characteristics such as first-line anti-tubercular drug resistance. Despite important recent medical innovation, many of the molecular mechanisms of this pathogen that allow its dissemination and ability to establish infections are still not clear. Many risk factors are known to predispose to tuberculosis infection, the most important of these being immunosuppression by various mechanisms. The systemic autoimmune rheumatic diseases encompass a group of clinically heterogeneous diseases that have a common pathogenical end-point: immune dysregulation characterized by overreactive cellular and humoral response. These patients are treated with long-term immunosuppressive drugs in most cases, diminishing disease activity but exposing the patient to possible complications such as life-threatening infections. The combination of immune dysregulation of the autoimmune disease and concomitant immunosuppressive therapy leads to a high incidence of active tuberculosis infection. These patients have a tendency of presenting with extrapulmonary disease and a higher mortality rate. Unfortunately, developing countries present higher incidences of tuberculosis in their population and tend to use nonspecific diagnostic methods for rapid detection and eradication. Current trends in developed countries consist of employing powerful molecular tools, such as Spoligotyping or MIRU-VNTR, for genotyping that allow diagnosis with high sensitivity and specificity. The precise identification of tuberculous strains gives previously unknown insight to understanding the molecular epidemiologic aspects of tuberculosis transmission and can predict patient response to treatment in some cases. Our team believes that this could be the first step towards tuberculosis infection control and even eradication, offering an improved quality of life to rheumatic patients.
\end{abstract}

\section{Tuberculosis (TB): why in these patients and what is behind it?}

A third of the world's population is infected with the TB bacilli, making it the most disseminated mycobacterial infection on our planet. The World Health Organization (WHO) estimates on a global scale that 10.4 million of people had TB in 2016 and 16\% of these patients died. Even though important achievements have been made in the medical field during the last century, 1.66 million patients died (in 2016) in the hands of this old enemy, probably the oldest pathogen registered in human medicine [1]. It is clear TB thrives on being a "social pathogen" (but not necessarily friendly) because of its many targets among the population that it prefers infecting, such as: immunosuppressed patients, health workers, social workers, hospital cleaning staff, food servers and slaughterhouse workers [2]. The question is why this specific population? The answer could be that these people are immunosuppressed either by drugs, viruses (such as Human Immunodeficiency Virus [HIV]) or congenital conditions. They have a high risk of being in closer contact with the carriers of the bacilli due to their profession because of their interaction with infected

${ }^{*}$ Correspondence to: Oscar Enrique Pizano Martínez, Departamento de Clínicas Médicas, Centro Universitario de Ciencias de la Salud, Universidad de Guadalajara. Sierra mojada No. 950. Col. Independencia. CP. 44340, Guadalajara, Jalisco. México, Tel. 52 (33)10585200. Ext. 33635; E-mail: sorrento80@hotmail.com

Received: December 29, 2018; Accepted: January 21, 2019; Published: January 24,2019 
individuals or even with infected animals like cattle in a zoonosis context. The fact is that its epidemiological aspects are complex because other environmental factors like malnutrition, cigarette smoking and overcrowding have been identified as risk factors for TB development. On the other hand, researchers have still not been able to discern why only $5-10 \%$ of the more than 2 billion people infected by TB have a lifetime risk of developing active tuberculosis [3].

The major biological mechanism for acquiring TB infection has been previously described and consists of the inhalation of contaminated drops. Inhaled droplets descend into the lower airways, where microbes encounter alveolar macrophages $(M \varnothing)$ and submucosal dendritic cells $(D C s)$. Both are named "the sentinels of the respiratory system" because of their skill to recognize microbes through their Pattern Recognition Receptors (PRRs), such as Toll Like Receptor-2 (TLR-2), which has a major role in recognizing glycolipid and lipoprotein components present on the mycobacterial wall [4]. After the bacilli recognition, an intracellular signaling cascade mediated by the Myeloid differentiation primary response 88 (MyD88) protein is initiated. MyD88 acts as an essential adaptor protein for adequate immune response for two reasons: first, it increases the phagocytic activity to engulf the bacilli into phagolysosomes; this signaling pathway also promotes pro-inflammatory cytokine secretion to wake up a stronger cellular response able to fight against TB [5]. However, after many millennia of contact with humans the TB bacilli has developed many means of immune evasion. One of these is the tryptophan-aspartate containing coat protein (TACO), which prevents phagosome-lysosome binding, making possible the intracellular survival of the bacilli [6]. For this, MØ and DCs are its main reservoir in the organism.

The adaptive immune system mounts a dominant Th1 response directed by $M \emptyset$ and $D C s$ because both present microbial peptides to $\mathrm{CD}^{+} \mathrm{T}$ cells via Major Histocompatibility Complex Class II (MHC-II) molecules in lung lymph nodes. This activates $\mathrm{CD} 4^{+}$and other immune cells which start to secrete numerous cytokines such as: Interferon- $\gamma$ $($ IFN- $\gamma$ ), Tumor Necrosis Factor- $\alpha$ (TNF $\alpha)$, Interleukin-1 $\beta$ (IL- $1 \beta)$, Interleukin-6 (IL-6), Interleukin-21 (IL-21) and Interleukin-12P40 (IL-12p40). This mechanism of activation may also be done directly by bacteria disseminating from the lung to the lymph node. The activated $\mathrm{T}$ cells are subject to clonal expansion and migrate out from the lymph nodes as effector T cells; this event occurs usually around 15-18 days post infection [7]. Once at the site of infection, they secrete IFN- $\gamma$, resulting in a complete microbe eradication or inflammation perpetuation. On the other hand, $M \varnothing$ secretes Transforming growth factor beta- $\beta$ (TGF- $\beta$ ), a protein that induces tissue remodeling and wound healing. The dynamic process between chronic inflammation and tissue remodeling conduces to the granuloma formation. The granuloma is a hosts' containment effort in response to an infection and contains a nucleus of necrotic lung tissue surrounded by $M \emptyset$, fibroblasts, DCs, neutrophils, B cells and some T cells subsets. All of these cells secrete cytokines and chemokines to ensure the continuous mobilization of granulocytes to the granuloma [8]. The traditional literature states, "The bacteria residing in the granuloma persist in a dormant state and proliferates only if the host's immune system is weakened due to any reason like Immunosuppressive drugs consumption, $\mathrm{HIV}^{+}$, etc. However, recent research suggests the formation of a type of biofilm called "Necrosis-Associated Extracellular Clusters (NECs) in the granuloma which contains active bacilli that are protected from the immune response and may be the basis of TB reactivation [9].The immune response to TB is mediated by cellular response and inflammation; together they play a major role in $\mathrm{TB}$ control. It has been shown that a complex and optimal immune system are needed to prevent TB infection; many patients unfortunately have a concomitant condition that compromises the immune response being a predictor for TB establishment or eradication. By understanding the biological processes involved in TB infection and/or eradication we may then understand how other disease conditions where the immune response is aberrant predisposes to infection, such as in Systemic Autoimmune Rheumatic Diseases (SARDs).

\section{SARD: origin and pathology}

\section{What does not kill you makes you stronger is not always true}

SARDs are a wide and complex variety of illnesses that cause chronic degeneration in many tissues of the human body. The pathological process affects cartilage, muscle, bones, tendons and ligaments, which act like targets for SARDs establishment [10]. Every SARD has clinical relevance, but we must recognize that some of them have more clinical impact than others, thus; the frequency and complexity of some SARD are higher than others among the world population as is shown by many reports (Table 1). Multiple genetic, epigenetic and environmental risk factors have been identified for SARDs development [10]. Each one of these triggers converges on a final endpoint: immune system dysregulation.

Although it is not our main objective, there are many major theories about SARDs development. One is based on sun radiation. It has been postulated that ultraviolet (UV) radiation could be a trigger for rheumatic disease because some specific geographic areas around the world present a positive correlation among high UV light ratio and genetic mutations, mainly by thymine dimers formation, which are found in immune cells from SARDs patients. Another is based on drug consumption as an inducer for SARD development. The response to these drugs are involved with the genetic background itself because a low efficiency to metabolize products that have to be acetylated, alters the Lymphocyte Function-Associated Antigen- 1(LFA-1) gene expression in B lymphocyte turning them into super reactive cells. Considering the high incidence of SARDs in the female population, hormones may be involved too. In murine models, estrogen and prolactin promote a phenotypic change from $B$ cell to autoreactive $B$ cell [11]; furthermore, oral contraceptives were shown to slightly increase the risk for Systemic Lupus Erythematous (SLE) development twofold [12]; however, it appears to be a protective factor for Rheumatoid Arthritis (RA) [13]. Some infections like Epstein Barr virus, although the molecular mechanism is not well understood, have been proposed to interact closely with B lymphocytes and plasmacytoid dendritic cells promoting auto-antibody formation and interferon- $\alpha$ (IFN- $\alpha$ ) secretion that promote immune dysregulation and the development of chronic inflammation [14].

Treatment schemes for these diseases are long term and usually include steroids and/or immunosuppressants, increasing the risk of acquiring a serious infectious disease from common or opportunistic microorganisms $[15,16]$. The relationship between SARDs and microbial infections is a complicated one. As mentioned above, some microorganisms seem to enhance the development of these diseases. At the same time, the intrinsic immune dysregulation combined with immunosuppressive treatments seems to be responsible for the high incidence of opportunistic infections in these patients [17].

In this context, we could imagine that if we have a strong immune response, we must be able to react against any enemy and control every risk of getting sick, in other words: "if our immune system response is exaggerated, we must be protected, then; what does not kill you makes you 
Table 1. SARDs, clinical aspects and TB incidence

\begin{tabular}{|c|c|c|c|}
\hline Autoimmune Systemic Diseases & Description & Immunosuppressants Used & Incidence of TB [patient years] \\
\hline \multirow{3}{*}{ Systemic Lupus Erythematous (SLE) } & $\begin{array}{l}\text { - Chronic autoimmune inflammatory disease } \\
\text { that can affect the majority of organs and } \\
\text { tissues. }\end{array}$ & $\begin{array}{l}\text { - Hydroxychloroquine } \\
\text { - NSAIDs } \\
\text { - Glucocorticoids }\end{array}$ & \multirow{3}{*}{153 to 2450 cases per 100,000 [34] } \\
\hline & - Heterogeneous clinical presentation. & $\begin{array}{l}\text { - Azathioprine } \\
\text { - Mycophenolate Mofetil } \\
\text { - Methotrexate }\end{array}$ & \\
\hline & $\begin{array}{l}\text { - Unpredictable disease course } \\
->90 \% \text { cases in women }[77,78] \text {. }\end{array}$ & $\begin{array}{l}\text { - Cyclophosphamide } \\
\text { - Rituximab } \\
\text { - Calcineurin Inhibitors [79] }\end{array}$ & \\
\hline \multirow{3}{*}{ Rheumatoid Arthritis (RA) } & $\begin{array}{l}\text { - Chronic systemic inflammatory disease of } \\
\text { unknown cause that primarily affects joints }\end{array}$ & $\begin{array}{l}\text { - NSAIDs } \\
\text { - Glucocorticoids } \\
\text { - Methotrexate } \\
\text { - Chloroquine } \\
\text { - Hydroxychloroquine } \\
\text { - Sulfasalazine }\end{array}$ & \multirow{3}{*}{6.4 to 134 per $100,000[40]$} \\
\hline & $\begin{array}{l}\text { - Potential for extra-articular features, } \\
\text { including: Rheumatoid nodules, increased } \\
\text { CV disease morbidity/mortality and lung } \\
\text { involvement }\end{array}$ & $\begin{array}{l}\text { - Leflunomide } \\
\text { - TNF- } \alpha \text { Antagonists } \\
\text { (Adalimumab, Etanercept, Infliximab, } \\
\text { Certolizumab pegol and Golimumab) } \\
\text { - Rituximab }\end{array}$ & \\
\hline & $\begin{array}{l}\text { - Most prevalent chronic inflammatory } \\
\text { disease }[80,81]\end{array}$ & $\begin{array}{l}\text { - Tocilizumab } \\
\text { - Abatecept } \\
\text { - Tofacitinib }[82,83]\end{array}$ & \\
\hline \multirow[t]{2}{*}{ Ankylosing Spondylitis (AS) } & $\begin{array}{l}\text {-Chronic inflammatory arthritis characterized } \\
\text { by sacroiliitis, enthesitis and a marked } \\
\text { propensity for sacroiliac joint and spinal } \\
\text { fusion }\end{array}$ & \multirow{2}{*}{$\begin{array}{l}\text { - NSAIDs } \\
\text { - Glucocorticoids } \\
\text { - TNF- } \alpha \text { Antagonists } \\
\text { - Secukinumab } \\
\text { - Sulfasalazine } \\
\text { - Methotrexate [85] }\end{array}$} & \multirow{2}{*}{$\begin{array}{l}123.1 \text { per } 100,000 \text { (this is in high-incidence } \\
\text { countries, in low-incidence countries there is } \\
\text { no increased risk when compared to general } \\
\text { population) }[43,44] \text {. }\end{array}$} \\
\hline & $\begin{array}{l}\text {-Potential for extra-articular features, } \\
\text { including: anterior uveitis, psoriasis and } \\
\text { chronic inflammatory bowel disease [84] }\end{array}$ & & \\
\hline \multirow{3}{*}{ Systemic Sclerosis (SSc) } & $\begin{array}{l}\text {-Immune-mediated rheumatic disease } \\
\text { characterized by fibrosis of the skin and } \\
\text { internal organs and vasculopathy }\end{array}$ & \multirow{3}{*}{$\begin{array}{l}\text {-Methotrexate } \\
\text {-Mycophenolate Mofetil } \\
\text {-Cyclophosphamide } \\
\text {-Glucocorticoids } \\
\text {-Azathioprine } \\
\text {-Intravenous Immunoglobulin (IVIG) } \\
\text {-Rituximab }[88,89]\end{array}$} & \multirow{3}{*}{414 per $100,000[49]$} \\
\hline & -Clinical and biochemical heterogeneity & & \\
\hline & $\begin{array}{l}\text {-Has high mortality (greater than any other } \\
\text { rheumatic disease) }[86,87]\end{array}$ & & \\
\hline & $\begin{array}{l}\text { - Idiopathic inflammatory myopathy with } \\
\text { characteristic cutaneous findings }\end{array}$ & \multirow[b]{2}{*}{$\begin{array}{l}\text { - Hydroxychloroquine } \\
\text { - Glucocorticoids } \\
\text { - Methotrexate } \\
\text { - Azathioprine } \\
\text { - Cyclosporine, } \\
\text { - Cyclophosphamide } \\
\text { - Leflunomide } \\
\text { - Mycophenolate Mofetil } \\
\text { - Rituximab } \\
\text { - IVIG } \\
\text { - TNF-Antagonists [91] }\end{array}$} & \multirow[b]{2}{*}{305 per $100,000[46]$} \\
\hline Inflammatory Myopathies (IM) & $\begin{array}{l}\text { - Most frequently affects the skin and } \\
\text { muscles but may also affect the joints, } \\
\text { esophagus and lungs [90] }\end{array}$ & & \\
\hline \multirow[t]{2}{*}{ Sjögren's Syndrome (SS) } & $\begin{array}{l}\text { - Chronic inflammatory disorder } \\
\text { characterized by lymphocytic infiltrates in } \\
\text { exocrine organs }\end{array}$ & \multirow{2}{*}{$\begin{array}{l}\text { - Glucocorticoids } \\
\text { - Hydroxychloroquine } \\
\text { - Methotrexate } \\
\text { - Cyclophosphamide } \\
\text { - IVIG } \\
\text { - Rituximab [92] }\end{array}$} & \multirow{2}{*}{255 per $100,000[28]$} \\
\hline & $\begin{array}{l}\text { - Most individuals present with sicca } \\
\text { symptoms (xerophthalmia, xerostomia and } \\
\text { parotid gland enlargement) [92] }\end{array}$ & & \\
\hline
\end{tabular}

stronger". It would be nice to say that sentence is true, but obviously it is not. This robust and uncontrolled immune response combined with immunosuppressive drugs, and the infections they predispose to, could end up killing these patients. We can see that this phrase sometimes is unfortunately just a myth.

\section{SARDs and TB: what is the relationship?}

Molecular defects in the innate and adaptive immune system of patients with systemic autoimmune diseases may increase the risk of infection even when not on immunosuppressive therapy. Some of these defects specifically predispose to TB infections. It has been reported that in SLE patients, T cells tend to have a decreased mitogeninduced cytotoxicity, Interleukin-2 (IL-2) production is decreased and its function dysregulated, causing some immune response defects such as: decreased activation-induced cell death (AICD), decreased number and function of Treg cells and decreased cytotoxic activity [18-20]. In RA patients, the $\mathrm{T}$ cell receptor (TCR) repertoire loses diversity in its protein arrangement when we compare memory and naïe $\mathrm{T}$ cells, affecting their multiclonal growth, which may delay an adequate immune response [21]. On the other hand, various autoimmune diseases have something in common: the presence of anti-Fc $\gamma$ receptor autoantibodies, which alters the correct macrophage biological function and predisposes to infections [22-23]. In this context, it is intuitive that intrinsic immune dysregulations leading to the presentation of SARDs predispose to infection even before the use of immunosuppressive treatment. 
Anti-inflammatory therapy protocols for SARDs tend to be the most important cause of infections in this patient population. These drugs suppress the immune response by various mechanisms (Table 1) and many ultimately impair normal T-cell function or reproduction; this by itself predisposes to TB infection considering the importance of $T$ cell response in controlling these infections [24-25]. A good example of this is biological therapy based on Anti-Tumor Necrosis Factor alpha (anti-TNF-alpha) antibodies. This is a relatively new type of treatment for many autoimmune diseases, which has shown excellent results and has improved life quality and expectancy. Despite its benefits, it has been linked to an increased risk of fungal and bacterial infection and especially promoting the reactivation of latent tuberculosis. This is due to hindering the activation of $\mathrm{CD}^{+} \mathrm{T}$ cells, the autophagy in macrophages and inducing apoptosis of certain immune cells. In a few years, it has shaped the epidemiological landscape of TB infection in this group of patients [26-27].

Considering the facts mentioned beforehand, patients with an SARD have a two-fold increased risk of acquiring an active TB infection when compared with the general population. This been observed in patients with SARDs such as SLE, RA, Ankylosing Spondylitis (AS), Systemic Sclerosis (Ssc), Inflammatory Myopathies (IM) and Sjögren's Syndrome (SS) [28]. Although the symptoms and clinical aspects of every SARD are different, they share a common denominator: the treatment of these diseases is glucocorticoids therapy, which in turn have been associated with the development of active TB when with higher doses of 10 milligrams (mg) per day and accumulated doses higher than $700 \mathrm{mg}$ [29]. There is also a relationship between active TB and cumulative dose of Prednisolone and median daily dose of Prednisolone before diagnosis [30-33].

Patients with SLE have a higher incidence of active TB compared to the general population in countries where TB is endemic (153 to 2450 cases per 100,000 population) and a higher cumulative of Prednisolone doses [30,31,34]. These patients usually have high disease activity and severe renal and joint involvement [32,35-37]. The estimated presentation of extrapulmonary TB in the general population is $<20 \%$ while in SLE patients it is in $25-67 \%$ of all cases, carrying with it a difficult diagnosis and higher mortality rate $[31,32,38]$. Among SLE patients with a past history of tuberculosis before the development of SLE, the relapse rate is much higher when compared to the general population and in other rheumatic diseases. A study in Korea found that in a cohort of SLE patients that developed tuberculosis, $15.2 \%$ had a history of tuberculosis while in a cohort of RA patients only $2.4 \%$ had a history of TB before disease onset [39].

A recent systemic review revealed RA patients, when compared to the general population in many different countries, had a two-fold increase in risk of acquiring active TB when not exposed to TNFbiologics and a 4 -fold increase when these were employed. Other studies report similar results if increased incidence rates when compared to the general population. These patients also tend to present with higher rates of extrapulmonary disease, disseminated TB and mortality rates [40-42].

It has been observed that patients suffering AS that have not been treated with TNF-biologics have a higher risk of contracting active TB disease when compared to the general population of TB endemic countries [43]. However, in countries of low TB prevalence, the risk is the same when compared to the general population [44]. In both types of countries, the use of TNF-biologics increases the risk significantly.

Patients with Dermatomyositis (DM) with active TB had extrapulmonary disease in $42.85 \%$ of cases [45]; DM was found to be an independent risk factor for developing active TB and the incidence rate was 305 per 100,000 Person-Years [46]; another associated risk factor was a higher mean daily dose of steroids [47].

TB infection in patients with SSc was previously thought to be uncommon due to a small number of reported literature (mostly case reports). The only mentioned study was by Cowie [48], who in 1987 described a $40 \%$ incidence of tuberculosis in black South African gold miners with SSc and concluded that there was an association between tuberculosis and SSc independent of silica exposure or silicosis. However, a few recent studies have shed new light on this relationship. In one study, SSc was found to be an independent risk factor for developing active TB and the incidence was 414 per 100,000 PersonYears with a 33\% mortality rate [49]. In another, there was an increased incidence of tuberculosis amongst patients of SSc on Dexamethasone pulse therapy [50].

Without a doubt, TB has a great impact on SARD patients due to immune system alteration and immunosuppressant treatment. The clinical manifestation of TB can be not only pulmonary but also extrapulmonary, indicating that the relationship among SARD-TB is deadly in many cases.

\section{Molecular epidemiology of Mycobacterium tuberculosis: its application in clinical practice}

With the application of different Mycobacterium tuberculosis complex (MTBC) genotyping methods, the international community has made great strides in further understanding many biological and epidemiological aspects of the bacilli and has gotten a step closer to complete eradication on a global scale (although we are still far away from this goal). The basis of these advancements is by matching genotypes from different clinical isolates of MTBC and linking with classic epidemiologic approaches. Together, they constitute the pillar of many TB control programs in many countries [51].

These methods facilitate the evaluation of outbreaks in healthcare settings or in the community, identify previously unrecognized transmission events, improve contact investigations and identify "nontraditional" settings for transmission (bars and churches). New specific risk factors for recent transmission have been identified and high-risk subpopulations better identified for specific public health management (male sex, being young adult, urban residence, alcohol and drug use, being homeless, being exposed in crowded settings [eg, prisons]) [52]. The age-old question of the differentiation between reactivation and reinfection with MCTB was finally answered with these methods. In some of the first studies with these methods, $>30 \%$ TB cases of specific regions in low incidence countries were attributed to recent infection (in comparison to the previously believed $10 \%$ ). It was also possible to detect the presence of mixed infections (with two strains of MCTB in the same patient) in a few studies, especially in high prevalence countries [53].

It is also possible to evaluate drug susceptibility, its relationship with specific genotypes and epidemiologic links. The use of molecular epidemiology also led to the discovery of false-positive MTBC cultures from laboratory cross contamination (approximately 3\% of culture confirmed cases are from contamination) [54]. These methods have also paved the way for new phylogenetic studies and led to the identification of endemically circulating strains and variations in immunogenicity, pathogenesis (virulence factors) and clinical manifestations that could determine transmission, disease progression, severity and transmissibility [55]. 


\section{Molecular identification of TB: brief method description. Why not, why yes?}

\section{Conventional methods for TB identification}

We described above the relationship between SARDs and TB and how this interaction could become dangerous and lethal, but the next questions are: Do specific SARDs present similar TB genotypes or are they nonrelated? Is the TB genotype more influenced by the clinical and environmental characteristics of each patient? Why is it that in many countries with high SARD incidence and TB incidence, the molecular identification of TB in these patients is not made? Current TB diagnosis continues to be based on useful but not specific methods, especially in developing countries. We must remember that TB could be originated by different members of the MTBC, which include: Mycobacterium tuberculosis, Mycobacterium bovis, Mycobacterium africanum, Mycobacterium microtti, Mycobacterium caprae, Mycobacterium pinnipedii, Mycobacterium canetii; all of these are capable of promoting disease because they share $99.7 \%$ of genetic homology, genes where the antigenicity resides [56]. In this context, smear microscopy by ZiehlNeelsen stain and chest $\mathrm{x}$-rays are not capable of giving us specific information about which specific tuberculous bacilli is present. On the other hand, the same problem is present if we use the interferon gamma release assays test (IGRAs). With IGRAs, we can determine immunologic evidence of TB infection ("germs in the body") by measuring IFN- $\gamma$ secreted by the patient's T-lymphocytes (QFT) or the number of IFN- $\gamma$-secreting lymphocytes (T-SPOT) upon ex vivo stimulation with $M$. tuberculosis-specific antigens. These antigens are not found in Bacille Calmette-Guerin (BCG) vaccine strains or most Nontuberculosis Mycobacteria (NTM) species (except Mycobacterium marinum, Mycobacterium kansasii, Mycobacterium szulgai, and Mycobacterium flavescens). However this is purely a diagnostic method and does not have the capability to identify specific strains of MTBC [57].

Microbial cultures are still used worldwide and have a high specificity for diagnosis. However, this method presents many disadvantages such as needing qualified staff, high costs, specialized equipment and appropriate installations; all of this makes it a complex method, especially for developing countries [58]. The current tendency to identify pathogens is to use tools that allow us to make a good diagnosis but with low costs, accuracy and simplicity which in turn, allows us to know the molecular aspects of TB for its dissemination, control and eradication.

\section{Gold standard molecular methods for TB identification}

Molecular epidemiology is defined as (1) the definition, identification, and tracking of relevant pathogen species, subspecies, strains, clones, and genes by means of molecular technology and evolutionary biology; and (2) the evaluation of the impact of a pathogen's genetic diversity on its relevant medical properties [59]. It is a field that has grown significantly in the past decades with the advent of newer and cheaper technology and the use of international databases. Its use in some countries is widespread for certain diseases (nationwide genotyping for all MTBC isolates in the United States of America) while in others it is confined to a few, well-funded laboratories (as is the case in most developing countries). As we mentioned above, MTBC strains share high nucleotide identity and only $0.3 \%$ offers polymorphic regions, which are the basis for molecular epidemiologic studies and can be identified and exploited for many research and clinical uses. The identification of these regions is realized by different molecular techniques that give important insight into the epidemiological aspects of TB.

\section{Restriction Fragment Length Polymorphism (RFLP) of IS6110 - Previous}

\section{Gold Standard for Molecular Typing of MTBC strains}

The first method used for genotyping MTBC was exploiting the unique Insertion Sequence (IS). IS elements are defined as small segments of DNA with a simple genetic organization capable of inserting at multiple sites in a target molecule [60,61]. IS6110 is found in almost every strain of M. tuberculosis, with 8-15 copies, but occasionally more than 20 or even one or two copies [62]. The technique for IS6110 amplification is done by southern blot hybridization, the number of copies and its genomic position between unrelated strains of $M$. tuberculosis allows comparisons and tracking of movements between these strains and their effect on human disease [63]. The main advantages of the IS6110-RFLP method are its high discriminatory power, reproducibility and the stability of its pattern. Some limitations to this procedure are the requirement of bacterial culture (it needs a large amount of high-quality DNA) with long turnaround times for reporting results, poor discriminatory power with those strains having few copies of IS6110 and the requirement of specialized software for interpretation of the data. These limitations would lead to the development of additional typing procedures; however, IS6110RFLP method remains the gold standard technique in molecular epidemiologic investigations of TB [64].

\section{Spoligotyping}

Spacer oligonucleotide typing (spoligotyping) is a PCR-based technique that identifies DNA polymorphisms within the Direct Repeat (DR) Locus of M.tuberculosis. This locus contains multiple, well-conserved 36 base pair DRs interspersed with nonrepetitive spacer sequences 35 to 41 base pairs long; strains vary in the number of DRs and in the presence or absence of particular spacers [65]. The region compromising the repeat plus the adjacent spacer has been termed the Direct Variable Repeat (DVR) [66]. Spoligotyping differentiates isolates of MTBC strains by determining the absence or presence of these 43 predefined spacers [67].

The first step of this method is mycobacterial DNA extraction, which can be done on many different types of clinical specimens and by different methods; the extraction from cultured isolates is the preferred technique. Once the DNA is extracted, the entire DR loci is amplified by Polymerase Chain Reaction (PCR) using two inversely oriented biotinlabeled primers complementary to the sequences of DRs [65]. After this, the PCR product is incubated over a membrane printed previously with 43 DNA spacers for its hybridization [65]. If the hybridization occurs, then a numerical binary code is made, assigning the number 1 , but if the hybridization does not occur, the assigned number is 0 . In that way, this binary code is composed 43 numbers that in turn, are separated in triplets, according with the combination of each triplet a number is assigned from 1 to 7 resulting into the octal code. This octal code is introduced in the international database, SpolDB4 or SITVIT. In this context, a SB (spoligotyping code) is registered and compared around the world, allowing us to track the genetic footprint of each isolated that we identify $[68,69]$. Spoligotyping has many advantages when compared to IS6110-RFLP, one of the most transcendental is using direct clinical samples without the need for bacterial culture isolation (saving time and money) and being a rapid method with results produced in $<48$ hours. This method is also useful for detecting isolates that IS6110-RFLP would not be able to because of few copies of IS6110. Other advantage are high reproducibility and a simple binary- 
result format (whereas sophisticated computer software is needed for IS6110-RFLP) that can be shared between laboratories through international databases. However, one limitation of spoligotyping is that it has less discriminatory power than IS6110-RFLP analysis for strains with high copy numbers $(\geq 6)$ of IS6110 (this is due to the fact that it targets a single genetic locus, covering $<0.1 \%$ of the $M$. tuberculosis complex genome, unlike IS6110 which is distributed over the whole mycobacterial genome) [68].

\section{Mycobacterial Interspersed Repetitive Units of Variable- Number Tandem Repeats (MIRU-VNTR) - The New Gold Standard for Molecular Typing of MTBC strains}

MIRU-VNTR is a PCR-based method that exploits various tandem repeat regions that are highly variable in their repeat numbers (hence the name VNTRs). MIRUs are mini satellite-like homologous containing VNTRs consisting of DNA sequences between 46-100 base pairs that are dispersed within different loci throughout the MTBC genome [70]. This method determines the length of the repeat and the size of the flanking regions of these MIRU to differentiate between different MTBC strains.

Around 41 different MIRU loci have been identified, but 24 have been standardized for genotyping and epidemiological studies, however some reports argue that 15 loci are the standard in epidemiological studies to get a discrimination power around 0.99 [71]. These various regions are amplified by PCR using specific primers for the 24 different loci and then, its size (base pairs) is determined by sodium dodecyl sulfate- polyacrylamide gel electrophoresis (SDS-PAGE) or in column chromatography. The obtained size is converted into numerical code to produce a digital format, which is then compared using an international database such as MIRU-VNTR plus web application for genotype identification [72]. This technique allows the tracking of the genetic footprint of each isolate that we need to identify. The use of 12 loci could be complemented with spoligotyping increasing its discriminatory power to $100 \%$ turning it in the new gold standard for molecular identification of TB [73].

\section{Molecular epidemiology of TB in rheumatic diseases: unexplored frontier}

The most recent analysis of the fourth international spoligotyping database, SpolDB4, described 1939 shared-types (STs) that represented 39,295 strains from 122 countries; without a doubt, this database has grown larger within the last 12 years since that report [74]. Many research articles report the presence of TB in SARD patients, who present both, pulmonary and extrapulmonary $\mathrm{TB}$, usually with fatal results $[28,30-50]$. However, in many countries the molecular diagnosis of TB is not applied yet in SARD patients and TB diagnosis is done using unspecific methods that may compromise the life of these patients; this is because clinicians may prescribe drugs that the bacilli is resistant to. If the clinician orders IGRA tests, chest X-rays, ZiehlNeelsen stains or even the Xpert MTB/RIF, which is based in PCR reaction and is currently recommended by the WHO, we will know if the patient has a tuberculous mycobacterial infection, but not which strain or its specific virulent factors [75]. A clear example of this is an infection by Mycobacterium bovis, which is inherently resistant to the antibiotic Pyrazinamide; a patient that is treated with first-line drugs will probably not be cured in this case [76]. It is clear that molecular diagnosis in SARD patients is needed because it is necessary to provide specific treatments. It is hard to believe that with so many technological advancements we are not yet capable of avoiding infections and death in SARD patients caused by an ancestral enemy like TB. We believe that much remains to be done in this field, powerful molecular tools such as Spoligotyping and MIRU-VNTR could allow us to understand the molecular aspects or molecular epidemiology that TB presents in this susceptible population of patients. This could be the first step towards TB infection control and even eradication, offering an improved quality of life to SARD patients.

\section{Conflicts of Interest}

The authors declare that there is no conflict of interest regarding the publication of this paper.

\section{Funding}

This project was supported by Secretaria de Educación Pública APOYO A LA INCORPORACIÓN DE NUEVOS PTC [grant number DSA/103.5/15/6927].

\section{References}

1. WHO (2017) TB disease burden. In Global Tuberculosis Report 2017. World Health Organization, Geneva, Switzerland pp 21-61.

2. Youakim S (2016) The occupational risk of tuberculosis in a low-prevalence population Occup Med (Lond) 66: 466-470. [Crossref]

3. van Crevel R, Ottenhoff TH, van der Meer JW (2002) Innate immunity to Mycobacterium tuberculosis. Clin Microbiol Rev 15: 294-309. [Crossref]

4. Blanc L, Gilleron M, Prandi J, Song OR, Jang MS, et al. (2017) Mycobacterium tuberculosis inhibits human innate immune responses via the production of TLR2 antagonist glycolipids. Proc Natl Acad Sci U S A 114: 11205-11210.

5. Cervantes JL (2017) Myd88 in Mycobacterium tuberculosis infection. Med Microbiol Immunol 206: 187-193.

6. Pieters $J$ (2008) Mycobacterium tuberculosis and the macrophage: maintaining a balance. Cell Host Microbe 3: 399-407. [Crossref]

7. Cooper AM (2009) Cell-mediated immune responses in tuberculosis. Annu Rev Immunol 27: 393-422. [Crossref]

8. Handzel ZT (2013) The Immune Response to Mycobacterium tuberculosis Infection in Humans. In: Mahboub B, Vats M (Eds) Tuberculosis Current Issues in Diagnosis and Management. London pp. 19-30.

9. Orme IM, Basaraba RJ (2014) The formation of the granuloma in tuberculosis infection. Semin Immunol 26: 601-609. [Crossref]

10. Deane KD, El-Gabalawy H (2014) Pathogenesis and prevention of rheumatic disease: focus on preclinical RA and SLE. Nat Rev Rheumatol 10: 212-228. [Crossref]

11. Saha S, Tieng A, Pepeljugoski KP, Zandamn-Goddard G, Peeva E (2011) Prolactin, systemic lupus erythematosus and autoreactive B Cells: lessons learnt from murine models. Clin Rev Allergy Immunol 40: 8-15.

12. Sanchez-Guerrero J, Karlson EW, Liang MH, Hunter DJ, et al. (1997) Past use of oral contraceptives and the risk of developing systemic lupus erythematous. Arthritis Rheum 40: 804-808.

13. Orellana C, Saevarsdottir S, Klareskog L, Karlson EW, Alfredsson L, et al. (2017) Oral contraceptives, breastfeeding and the risk of developing rheumatoid arthritis: results from the Swedish EIRA study. Ann Rheum Dis 76: 1845-1852.

14. Draborg AH, Duus K, Houen G (2012) Epstein-Barr virus and systemic lupus erythematosus. Clin Dev Immunol 2012: 370516. [Crossref]

15. Falagas ME, Manta KG, Betsi GI, Pappas G (2007) Infection-related morbidity and mortality in patients with connective tissue disorders: a systemic review. Clin Rheumatol 26: 663-670.

16. Listing J, Gerhold K, Zink A (2013) The risk of infections associated with rheumatoid arthritis, with its comorbidity and treatment. Rheumatology 52: 53-61.

17. Sakkas LI, Bogdanos DP (2016) Infections as a cause of autoimmune rheumatic diseases. Auto Immun Highlights 7: 13. [Crossref]

18. Barber C, Gold WL, Fortin PR (2011) Infections in the lupus patient: perspectives on prevention. Curr Opin Rheumatol 23: 358-365. [Crossref] 
19. Kis-Toth K, Comte D, Karampetsou MP, Kyttaris VC, Kannan L, et al. (2016) The selective loss of SLAMF4+ CD8+ T cells contributes to the decreased cytotoxic cell activity in systemic lupus erythematous. Arthritis Rheumatol 68: 164-173.

20. Lieberman LA, Tsokos GC (2010) The IL-2 Defect in Systemic Lupus Erythematous Disease Has an Expansive Effect on Host immunity. J Biomed and Biotechnol 740619.

21. Wagner UG, Koetz K, Weyand CM, Goronzy JJ (1998) Perturbation of the T cell repertoire in rheumatoid arthritis. Proc Natl Acad Sci US A 95: 14447-14452. [Crossref]

22. Durand V, Lamour A, Devauchelle V, Youinou P, Jamin C (2000) Fc-gamma receptor reactivity in nonorgan-specific autoimmune dseases. Clin Rev Allergy Immunol 18: 1126.

23. Yu X, Lazarus AH (2016) Targeting Fc?Rs to treat antibody-dependent autoimmunity. Autoimmun Rev 1: 510-512.

24. Li P, Zheng Y, Chen X (2017) Drugs for Autoimmune Inflammatory Diseases: From Small Molecule Compounds to Anti-TNF Biologics. Front Pharmacol 8: 1-12.

25. Spies CM, Strehl C, van der Goes MC, Bijlsma JW, Buttgereit F (2011) Glucocorticoids. Best Pract Res Clin Rheumatol 25: 891-900. [Crossref]

26. Harris J, Keane J (2010) How tumor necrosis factor blockers interfere with tuberculosis immunity. Clin Exp Immunol 161: 1-9.

27. Miller EA, Ernst JD (2009) Anti-TNF immunotherapy and tuberculosis reactivation: another mechanism revealed. J Clin Invest 119: 1079-1082.

28. Chang YS, Liu CJ, Ou SM, Hu YW, Chen TJ, et al. (2014) Tuberculosis infection in primary Sjögren's syndrome: a nationwide population-based study. Clin Rheumatol 33: $377-383$.

29. Font CV, Hernández-García C, Pato E, Morado IC, Salido M, et al. (2003) Incidence and characteristics of tuberculosis in patients with autoimmune rheumatic diseases. Rev Clin Esp 203: 178-182.

30. Sayarlioglu M, Inanc M, Kamali S, Cefle A, Karaman O, Gul A, et al. (2004) Tuberculosis in Turkish patients with systemic lupus erythematous: increased frequency of extrapulmonary localization. Lupus 13: 274-278.

31. Tam LS, Li EK, Wong SM, Szeto CC (2002) Risk factors and clinical features for tuberculosis among patients with systemic lupus erythematous in Hong Kong. Scand $J$ Rheumatol 31: 296-300.

32. Arenas-Miras MM, Hidalgo-Tenorio C, Jimenez-Alonso J (2013) Tuberculosis in patients with systemic lupus erythematosus: Spain's situation. Reumatol Clin 9: 369372 .

33. Jick SS, Lieberman ES, Pahman MU, Choi HK (2006) Glucocorticoid Use, Other Associated Factors, and the Risk of Tuberculosis. Arthritis Rheum 55: 19-26.

34. Erdozain JG, Ruiz-Irastorza G, Egurbide MV, Martinez-Berriotxoa A, Aguirre C (2006) High risk of tuberculosis in systemic lupus erythematous? Lupus 15: 232-235.

35. Kang I, Hwan-Park SH (2003) Infectious complications in SLE after immunosuppressive therapies. Curr Opin Rheumatol 15: 528-34.

36. Victorio-Navarra ST, Dy EE, Arroyo CG, Torralba TP (2006) Tuberculosis Among Filipino Patients With Systemic Lupus Erythematous. Semin Arthritis Rheum 26: 628-634.

37. Hou CL, Tsai YC, Chen LC, Huang JL (2008) Tuberculosis infection in patients with systemic lupus erythematous: pulmonary and extra-pulmonary infection compared. Clin Rheumatol 27: 557-563.

38. González-León R, Garrido RR, Chinchilla PE, García-Hernández FJ, Castillo-Palma MJ, et al. (2010) Tuberculosis in a cohort of patients with systemic lupus erythematous. Reumatol Clin 6: 256-61.

39. Yun JE, Lee SW, Kim TH, Jun JB, Jung S, et al. (2002) The incidence and clinical characteristics of Mycobacterium tuberculosis infection among systemic lupus erythematosus and rheumatoid arthritis patients in Korea. Clin Exper Rheumatol 20: $127-132$.

40. Baronett L, Barnetche T, Kahn V, Lacoin C, Richez C, et al. (2011) Incidence of tuberculosis in patients with rheumatoid arthritis. A systemic literature review. Joint Bone Spine 78: 279-284.

41. Yeh JJ, Wang YC, Sung FC, Kao CH (2014) Rheumatoid Arthritis Increases the Risk of Nontuberculosis Mycobacterial Disease and Active Pulmonary Tuberculosis. PLoS ONE.

42. Ishiguro T, Takayanagi N, Kagiyama N, Yanagisawa T, Sugita Y (2014) Characteristics of tuberculosis in patients with rheumatoid arthritis: a retrospective single-center study. Intern Med 53: 1291-8.
43. Kim HW, Park JK, Yang JA, Yoon YI, Lee EY, et al. (2014) Comparison of tuberculosis incidence in ankylosing spondylitis and rheumatoid arthritis during tumor necrosis factor inhibitor treatment in an intermediate burden area. Clin Rheumatol 33: 1307-1312.

44. De Vries MK, Arkema EV, Jonsson J, Bruchfeld J, Jacobsson LT, et al. (2017) Tuberculosis risk in ankylosing spondylitis, other spondyloarthritis and psoriatic arthritis in Sweden: a population-based cohort study. Arthritis Care Res (Hoboken) 70: 1563-1567.

45. Chen IJ, Tsai WP, Wu YJ, Luo SF, Ho HH, et al. (2010) Infections in polymyositis and dermatomyositis: analysis of 192 cases. Rheumatology (Oxford) 49: 2429-2437. [Crossref]

46. Wu PH, Lin YT, Yang YC, Lin YC (2015) The increased risk of active tuberculosis disease in patients with dermatomyositis - a nationwide retrospective cohort study. Sci Rep 5: 16303 .

47. Marie I, Hachulla E, Cherin P, Hellot MF, Herson S, et al. (2005) Opportunistic Infections in polymyositis and dermatomyositis. Arthritis Rheum 53: 155-165.

48. Cowie RL (1987) Silica-dust-exposed mine workers with scleroderma (systemic sclerosis). Chest 92: 260-262. [Crossref]

49. Ou SM, Fan WC, Chou KT, Yeh CM, Su VY, et al. (2014) Systemic sclerosis and the risk of tuberculosis. J Rheumatol 41: 1662-1669. [Crossref]

50. Ahmad QM, Shah IH, Nauman Q, Sameem F, Sultan J (2008) Increased incidence of tuberculosis in patients of systemic sclerosis on dexamethasone pulse therapy: A short communication from Kashmir. Indian J Dermatol 53: 24-25.

51. CDC (2004) National TB Controllers Association / CDC Advisory Group on Tuberculosis Genotyping. Introduction to Tuberculosis Genotyping. In Guide to the Application of Genotyping to Tuberculosis Prevention and Control. Atlanta, GA: US Department of Health and Human Services, CDC pp. 2-3.

52. Padmanesan N, Wood J, MacIntyre CR, Mathai D (2013) Risk Factors for Tuberculosis. Pulm Med 2013.

53. Borgdorff MW, van Soolingen D (2013) The re-emergence of tuberculosis: what have we learnt from molecular epidemiology? Clin Microbiol Infect 19: 889-901. [Crossref]

54. Barnes PF, Cave MD (2003) Molecular epidemiology of tuberculosis. $N$ Engl J Med 349: 1149-1156. [Crossref]

55. Mathema B, Kurepina NE, Bifani PJ, Kreiswirth BN (2006) Molecular epidemiology of tuberculosis: current insights. Clin Microbiol Rev 19: 658-685. [Crossref]

56. Kato-Maeda M, Rhee JT, Gingeras TR, Salamon H, Drenkow J, et al. (2001) Comparing genomes within the species Mycobacterium tuberculosis. Genome Res 11: 547-554.

57. Dunn JJ, Starke JR, Revell PA (2016) Laboratory Diagnosis of Mycobacterium tuberculosis Infection and Disease in Children. J Clin Microbiol 54: 1434-1441.

58. Caulfield AJ, Wengenack NL (2016) Diagnosis of active tuberculosis disease: From microscopy to molecular techniques. J Clin Tub Mycob Dis 4: 33-43.

59. Tibayrenc M (2009) Microbial molecular epidemiology: an overview. Methods Mol Biol 551: 1-12. [Crossref]

60. Mahillon J, Chandler M (1998) Insertion sequences. Microbiol Mol Biol Rev 62: 725 774. [Crossref]

61. Siguier P, Gourbeyre E, Chandler M (2014) Bacterial insertion sequences: their genomic impact and diversity. FEMS Microbiol Rev 38: 865-891. [Crossref]

62. Dale JW, Tang TH, Wall S, Zainuddin ZF, Plikaytis B (1997) Conservation of IS6110 sequence in strains of Mycobacterium tuberculosis with single and multiple copies. Tuber Lung Dis 78: 225-227.

63. Van Embden JD, Cave MD, Craword JT, Dale JW, Eisenach KD, et al. (1993) Strain Identification of Mycobacterium tuberculosis by DNA Fingerprinting: recommendations for a standardized methodology. J Clin Microbiol 31: 406-409.

64. Ei PW, Aung WW, Lee JS, Choi GE, Chang CL (2016) Molecular Strain Typing of Mycobacterium tuberculosis: a Review of Frequently Used Methods. J Korean Med Sci 31: 1673-1683. [Crossref]

65. Kamerbeek J, Schouls L, Kolk A, van Agterveld M, van Soolingen D, et al. (1997) Simultaneous detection and strain differentiation of Mycobacterium tuberculosis for diagnosis and epidemiology. J Clin Microbiol 35: 907-914. [Crossref]

66. Groenen PMA, Bunschoten AE, van Soolingen D, van Embden JD (1993) Nature of DNA polymorphism in the direct repeat cluster of Mycobacterium tuberculosis; application for strain differentiation by a novel typing method. Mol Microbiol 10: 1057-65. 
67. Vitol I, Driscoll J, Kreiswirth B, Kurepina N, Bennett KP (2006) Identifying Mycobacterium tuberculosis complex strain families using spoligotyping. Infect Genet Evol 6: 491-504

68. Jagielski T, Minias A, van Ingen J, Rastogi N, Brzostek A, et al. (2016) Methodological and Clinical Aspects of the Molecular Epidemiology of Mycobacterium tuberculosis and Other Mycobacterium. Clin Microbiol Rev 29: 239-290.

69. Dale JW, Brittain D, Cataldi AA, Cousins D, Crawford JT, Driscoll J, et al. (2001) Spacer oligonucleotide typing of bacteria of the Mycobacterium tuberculosis complex: recommendations for standardised nomenclature. Int J Tuberc Lung Dis 5: 216-219.

70. Supply P, Mazars E, Lesjean S, Vincent V, Gicquel B, et al. (2000) Variable human minisatellite-like regions in the Mycobacterium tuberculosis genome. Mol Microbio 36: 762-771.

71. Alonso-Rodríguez N, Martinez-Lirola M, Herránz M, Sanchez-Benitez M, Barroso P, et al. (2008) Evaluation of the new advanced 15-loci MIRU-VNTR genotyping tool in Mycobacterium tuberculosis molecular epidemiology studies. BMC Microbiol.

72. Supply P, Allix C, Cardoso Oelemann M, Rusch-Gerdes S, Willery E, et al. (2006) Proposal for standardization of optimized mycobacterial interspersed repetitive unit-variable-number tandem repeat typing of Mycobacterium tuberculosis. $J$ Clin Microbiol 39: 3563-3571.

73. Oelemann MC, Diel R, Vatin V, Hass W, Rüsch-Gerdes S, et al. (2007) Assessment of an optimized mycobacterial interspersed repetitive-unit-variable-number tandemrepeat typing system combined with spoligotyping for population-based molecular epidemiology studies of tuberculosis. J Clin Microbiol 45: 691-697.

74. Brudey K, Driscoll JR, Rigouts L, Prodinger WM, Gori A, et al. (2006) Mycobacterium tuberculosis complex genetic diversity: mining the fourth international Spoligotyping database (SpolDB4) for classification, population genetics and epidemiology. BMC Microbiol 6: 1-17.

75. WHO (2014) Testing and Managing Patients. In Xpert MTB/RIF Implementation Manual. Technical and operational "how-to": practical considerations. World Health Organization Geneva, Switzerland. pp 10-19.

76. Jong BC, Onipede A, Pym AS, Gagneux S, Aga RS, et al. (2005) Small PM. Does Resistance to Pyrazinamide Accurately Indicate the Presence of Mycobacterium bovis? J Clin Microbiol 43: 3530-3532.

77. Bertsias G, Cervera R, Boumpas DT (2015) Systemic Lupus Erythematous: Pathogenesis and Clinical Features In: Bijlsma JWJ, Hachulla E (Eds) EULAR Textbook on Rheumatic Diseases, United Kingdom BMJ pp. 476-505
78. Mohan C1, Putterman C2 (2015) Genetics and pathogenesis of systemic lupus erythematosus and lupus nephritis. Nat Rev Nephrol 11: 329-341. [Crossref]

79. Tunnicliffe DJ, Singh-Grewal D, Kim S, Craig JC, Tong A (2015) Diagnosis, Monitoring and Treatment of Systemic Lupus Erythematous: A Systemic Review of Clinical Practice Guidelines. Arthritis Care Res (Hoboken) 67: 1440-1452.

80. McInnes IB, Schett G (2011) The pathogenesis of rheumatoid arthritis. $N$ Engl J Med 365: 2205-2219. [Crossref]

81. Smolen JS, Aletaha D, McInnes IB (2016) Rheumatoid arthritis. Lancet 388: 2023 2038. [Crossref]

82. Singh JA, Saag KG, Bridges SL Jr, Akl EA, Bannuru RR, et al. (2015) American College of Rheumatology Guideline for the Treatment of Rheumatoid Arthritis. Arthitis Rheumatol 68: 1-26.

83. Byerk VP, Akhavan P, Hazlewood GS, Schieir O, Dooley A, et al. (2012) Canadian Rheumatology Association recommendations for pharmacological management of rheumatoid arthritis with traditional and biologic disease-modifying antirheumatic Drugs. J Rheumatol 39: 1559-1582.

84. Braun J, Sieper J (2007) Ankylosing spondylitis. Lancet 369: 1379-1390.90. [Crossref]

85. Ward MM, Deodhar A, Akl EA, Ermann J, Gensler LS, et al. (2005) American College of Rheumatology/Spondylitis Association of America/Spondyloarthritis Research and Treatment Network.

86. Denton CP, Khanna D (2017) Systemic sclerosis. Lancet 390: 1685-1699. [Crossref]

87. Allanore Y, Simms R, Distler O, Trojanowska M, Pope J, et al. (2015) Systemic sclerosis. Nat Rev Dis Primers 1: 15002. [Crossref]

88. Young A, Khanna D (2015) Systemic sclerosis: a systemic review on therapeutic management from 2011-2014. Curr Opin Rheumatol 27: 241-248.

89. Denton CP, Hughes M, Gak N, Vila J, Buch MH, et al. (2016) BSR and BHPR guideline for the treatment of systemic sclerosis. Rheumatology (Oxford) 55: 19061910. [Crossref]

90. Dalakas MC (2015) Inflammatory Muscle Diseases. N Engl J Med 372: 1734-1747.

91. Moghadam-Kia S, Aggarwal R, Oddis CV (2015) Treatment of inflammatory myopathy: emerging therapies and therapeutic targets. Expert Rev Clin Immunol 11: 1265-1275.

92. Stefanski AL, Tomiak C, Pleyer U, Dietrich T, Burmester GR, et al. (2017) The Diagnosis and Treatment of Sjögren's Syndrome. Dtsch Arztebl Int 114: 354-361. [Crossref]

Copyright: @2019 Vázquez-Del Mercado M. This is an open-access article distributed under the terms of the Creative Commons Attribution License, which permits unrestricted use, distribution, and reproduction in any medium, provided the original author and source are credited. 